\title{
Sango Language
}

National Cancer Institute

\section{Source}

National Cancer Institute. Sango Language. NCI Thesaurus. Code C154104.

A creole language spoken as an official language of the Central African Republic. 